\title{
Youth Perception of Legislative General Elections in Pidie Regency
}

\author{
Rozaili $^{1}$, Zulfikar ${ }^{2}$ \\ 12 University of Jabal Ghafur, Indonesia \\ rozaili@unigha.ac.id
}

\begin{abstract}
Democracy is a brilliant idea that changes the politics of the world. The emergence of democracy is something that is considered important because it is a political idea containing values that are indispensable as a reference for managing the life of the nation and a good state. Based on the description above, researchers can formulate the problem as follows: 1) What is the youth's response to the legislative elections in 2019? 2) What is the level of youth awareness towards the legislative elections in 2019? The approach used in this research is a quantitative approach with descriptive type. A quantitative approach with a descriptive type aims to explain, summarize various conditions, various situations, or various variables that arise in the community that become the object based on what is happening. From the results of the study found $37 \%$ of youth did not use their voting rights and $63 \%$ used their voting rights. This is the benchmark among young people so apathetic towards the politics that are running in this country. The disappointment that young people get from previous legislators is their benchmark for voting in this election, guided by this research, it will be the biggest disaster for youth in the world of politics. As for the youth who belong to the group chose almost half of them chose because of financial factors and encouragement from others and very few chose according to conscience, For this reason, they chose not to be involved in legislative elections this year, and to take care of more important matters according to them.
\end{abstract}

Keywords

youth perception; legislative elections; democracy

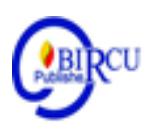

\section{Introduction}

Democracy is a brilliant idea that changes the politics of the world. The emergence of democracy is something that is considered important because it is a political idea containing values that are needed as a reference for managing the life of the nation in a country. In elections, citizens can give their voting rights both in the form of voting rights and the right not to vote. As a process and quality of democratic life in this country, legislative elections deserve the support of all the people of Indonesia. Not only is the function of elections to elect legislative representatives and or national leaders, but also because the election itself carries a substantial moral message so that the people elect people's representatives who have a conscience.

Democracy has become a central issue in the past decade related to the dynamics of social change and Indonesian state administration. People have high hopes for improvement as a result of the development of democracy in Indonesia, especially in the era of modernization. Indonesia, which is classified as a developing country in Southeast Asia, has resulted in many developments from the outside world who want to enter Indonesia or even force them to enter Indonesia. the modernization era which is marked by the rapid development of information and technology resulting in an increase in one's curiosity about 
various forms of information. This makes it seem as if the world without borders is the door to open windows, this term is known as globalization. Influences originating from the western world bring all negative and positive impacts. The rapid development among the people of Indonesia shows various developments. Starting from clothing fashion trends, lifestyles, and social order that changes with the emergence of a social gap in the social environment. (Prasetyo, 2019)

Politics is a technique that regulates and manages a country for a policy according to existing legislation. The youth will play a very important role in the political frame in the country, especially in elections held simultaneously with the presidential election in 2019, voters aged 17-30 years accounted for 30\% of the total electorate. Whether we realize it or not, true youth has a strategic role and function in accelerating development, including in the life process of the nation and state. Youth who are often referred to as the hope of the nation are actors in development.

\section{Review of Literature}

\subsection{Perception}

There are various notions of perception. Perception can be interpreted as a point of view or a person's perspective on an object. Someone's perception will influence the decision making process. If someone's perception is good or positive about a thing, then the decision making will be in harmony with that perception or vice versa.

According to Davidoff, quoted by Walgito (2010: 89) that is perception is an integrated activity within individuals will participate actively in perception. Based on this, the perception can be expressed because of feelings, thinking ability, individual experiences are not the same, the results of perception may differ between one individual with another individual. Meanwhile, According to Slameto (2010: 102) perception is a process involving the entry of messages or information into the human brain, through the perception of humans continuously in contact with the environment.

\subsection{Definition of Youth}

Youth are individuals who when seen physically are experiencing development and are psychologically undergoing emotional development, so that youth is a human resource Development both now and later that will replace the previous generation. Youth are individuals with a dynamic character, even volatile and optimistic but do not yet have stable emotional control. Youth face a period of social and cultural change.

According to Mulyana (2011: 5) youth are individuals who have dynamic characters, meaning that they have volatile, optimistic characters and have not been able to control stable emotions. Furthermore, according to Law Number 40 of 2009 concerning youth article 1 paragraph (1), defines that "Youth are Indonesian citizens who enter an important period of growth and development aged 16 (sixteen) to 30 (thirty) years". Based on the above understanding, it can be concluded that youth are men aged 16-30 years who are biologically showing signs of maturity.

\subsection{Definition of general election}

Elections are held with the aim of electing Members of the People's Legislative Assembly, Regional Representatives Council, and Regional People's Representative Council and the General Election is a means of implementing people's sovereignty which is carried out directly, publicly, freely, confidentially, honestly and fairly in the Unitary State of the 
Republic of Indonesia based on the Pancasila and the Law the 1945 Constitution of the Republic of Indonesia.

According to Tricahyo (2009: 6) Universal General Election is an instrument to realize the sovereignty of the people who intend to form a legitimate government and a means of articulating people's aspirations and interests. Meanwhile, according to Haris (2006: 10) Is one form of political education For the people, which is direct, open, mass, which is expected to be able to educate political understanding and increase public awareness about democracy.

\section{Research Method}

The method used in this research is a quantitative approach with descriptive type. As stated by Bungin (2008: 36) quantitative approach with descriptive type aims to explain, summarize the various conditions, various situations, or various variables that arise in the community that becomes the object based on what happened. The purpose of this research is to find out the response of youth in the district of Pili district mila to the legislative general election in 2019 and supported by library studies to strengthen research analysis in making conclusions.

\section{Discussion}

The youth response to legislative elections in 2019. research that will be described is based on data obtained from this study the authors use quantitative methods. Where the answers to questions are tabulated and explained according to the respondents' answers. Based on the data obtained from the results of the study, it can be seen in the following table:

To find out the opinion of respondents regarding whether you used your voting rights during the legislative elections, can be seen in the table below.

Table 1. To find out the responses of respondents whether they used their right to vote during The 2019 legislative elections.

\begin{tabular}{|l|l|l|l|}
\hline No & Alternative Answers & F & $0 \%$ \\
\hline A & Yes & 63 & $63 \%$ \\
\hline B & no & 37 & $37 \%$ \\
\hline & Total (n) & 100 & $100 \%$ \\
\hline
\end{tabular}

Based on the table above shows that the majority (63\%) of respondents said they used their voting rights during legislative elections and a small portion $(37 \%)$ of respondents did not use their voting rights during legislative elections.

To find out the opinions of respondents what are the reasons for using voting rights during legislative elections, can be seen in the following table:

Table 2. What are the reasons for using voting rights during legislative elections

\begin{tabular}{|l|l|l|l|}
\hline No & Alternative Answers & F & $0 \%$ \\
\hline A & awareness & 19 & $19 \%$ \\
\hline B & Other people's encouragement & 26 & $26 \%$ \\
\hline C & Financial Factor & 18 & $18 \%$ \\
\hline D & Not use voting & 37 & $37 \%$ \\
\hline & Total(n) & 100 & $100 \%$ \\
\hline
\end{tabular}


Based on the table above shows that very few (19\%) of respondents said they chose the legislature based on their desires and a small portion (26\%) said they chose the legislature based on the encouragement of others and a few (18\%) respondents said they chose the legislature based on financial factors and a small portion (37\%) of respondents who answered did not vote.

To find out the opinion of respondents regarding Have you seen, heard and watched the campaign of candidates for the legislature, can be seen in the following table:

Table 3. below is to find out respondents choosing legislative candidates based on listenin to and watching legislative candidates' campaigns

\begin{tabular}{|l|l|l|l|}
\hline NO & Alternative Answers & F & $0 \%$ \\
\hline A & Ever & 34 & $34 \%$ \\
\hline B & Not do & 66 & $66 \%$ \\
\hline C & Total & 100 & $100 \%$ \\
\hline
\end{tabular}

From the table above shows a small portion (34\%) of respondents who said they had watched and heard the legislative campaign and the majority $(66 \%)$ of respondents said they had never heard and seen the campaign of candidates for the legislature

To find out the opinion of respondents how the ability of candidates for legislative members of Pidie Regency, can be seen in the following table:

Table 4. How is the ability of Candidates for District legislative members

\begin{tabular}{|l|l|l|l|}
\hline NO & Alternative Answers & F & $0 \%$ \\
\hline A & Very capable & 6 & $6 \%$ \\
\hline B & Able & 21 & $21 \%$ \\
\hline C & Not able & 35 & $35 \%$ \\
\hline D & Not know & 38 & $38 \%$ \\
\hline & Total (n) & 100 & $100 \%$ \\
\hline
\end{tabular}

From the table above shows very few $(6 \%)$ of respondents stated that candidates for the legislature were very capable of becoming members of the regional representative council and a small portion $(21 \%)$ of respondents said they were capable and a small portion $(27 \%)$ of respondents said they were unable and more than half (54\%) respondents said they did not know the ability of Pidie Regency legislative candidates.

To find out the opinion of the respondent whether the legislative candidate you chose is well-established in financial matters, see the following table:

Table 5. Below is to find out respondents regarding the elected legislative candidates who are already well-established in financial matters

\begin{tabular}{|l|l|l|l|}
\hline No & Alternative Answers & F & $0 \%$ \\
\hline A & Yes & 67 & $67 \%$ \\
\hline B & No & 33 & $33 \%$ \\
\hline & Total(n) & 100 & $100 \%$ \\
\hline
\end{tabular}


From the table above it can be seen that the majority (67\%) of respondents chose legislative candidates who were already financially well established and less than half (33\%) of respondents chose not based on the candidates' legislative ability.

To find out the respondent's opinion Do you directly see the success team that you choose to make house-to-house visits to do dirty politics, can be seen in the following table:

Table 6. below is to find out the respondent regarding whether the respondent saw directly the timses that the respondent chose to make door-to-door visits on dirty politics.

\begin{tabular}{|l|l|l|l|}
\hline No & Alternative Answers & F & $0 \%$ \\
\hline A & Yes & 71 & $71 \%$ \\
\hline B & Not & 29 & $29 \%$ \\
\hline & Total (n) & 100 & $100 \%$ \\
\hline
\end{tabular}

From the above table it can be concluded that the majority (71\%) of respondents saw the legislative candidate's timses do house-to-house visits and conducted dirty politics while a small portion (29\%) did not see the timses of legislative candidates doing dirty politics.

From the results of the table above, it can be concluded that the interest of youth in distributing their voting rights in the 2019 legislative elections is more than that of those not voting. But there are many voters who vote based on the encouragement of others and financial factors even many of them do not know the ability of the legislative candidates they choose

The level of youth awareness towards the legislative elections in 2019 the level of youth awareness of the general election can be described according to the table below to find out the opinion of respondents regarding whether you determine the choice of candidates for legislative members based on the campaign that you see. Can be seen in the following table:

Table 7. To find out whether respondents determine the choice of candidates for legislative Candidates based on the campaign viewed.

\begin{tabular}{|l|l|l|l|}
\hline NO & Alternative Answers & F & $0 \%$ \\
\hline A & Yes & 21 & $21 \%$ \\
\hline B & no & 79 & $79 \%$ \\
\hline & Total (n) & 100 & $100 \%$ \\
\hline
\end{tabular}

From the table above we can conclude that a few (21\%) of respondents make choices based on the campaign seen and the majority (79\%) states that they make choices not based on the campaign they see.

To find out the opinion of respondents regarding whether you use your voting rights in the 2019 legislative election because they have a sense of awareness as citizens, can be seen in the table below

Table 8. To find out whether respondents use voting rights in 2019 legislative elections because they have a sense of awareness as citizens

\begin{tabular}{|l|l|l|l|}
\hline NO & Alternative Answers & F & $0 \%$ \\
\hline A & Yes & 41 & $41 \%$ \\
\hline B & no & 59 & $59 \%$ \\
\hline & Total (n) & 100 & $100 \%$ \\
\hline
\end{tabular}


From the table above it can be seen that less than half of the facilitators (41\%) of respondents use voting rights in 2019 pileg because they have a sense of awareness as citizens and more than half (59\%) respondents use voting rights in 2019 pileg because they have a sense of awareness as citizens.

To find out the respondent's opinion about your parents influencing you in determining the choice to choose one of the candidates in the 2019 legislative election, can be seen in the following table:

Table 9. below to find out whether the respondent's parents influence in Determine the choice to choose one of the candidates in the 2019 legislative election

\begin{tabular}{|l|l|l|l|}
\hline NO & Alternative Answers & F & $0 \%$ \\
\hline A & Yes & 14 & $14 \%$ \\
\hline B & Tno & 86 & $86 \%$ \\
\hline & Total $(\mathrm{n})$ & 100 & $100 \%$ \\
\hline
\end{tabular}

From the table above it can be seen that very few (14\%) of respondents stated that parents influenced him in legislative elections and generally $(86 \%)$ respondents said parents did not influence him in legislative elections.

To find out whether the respondent feels that he is ignorant of the Pileg, you can look at the table below.

Table 10. Do respondents feel indifferent about Pileg

\begin{tabular}{|l|l|l|l|}
\hline NO & Alternative Answers & F & $0 \%$ \\
\hline A & Yes & 56 & $56 \%$ \\
\hline B & no & 44 & $44 \%$ \\
\hline & Total(n) & 100 & $100 \%$ \\
\hline
\end{tabular}

From the above table it can be seen that more than half $(56 \%)$ feel ignorant of legislative elections and less than half (59\%) of respondents use voting rights in 2019 pileg because they have a sense of awareness as citizens.

From the results of the questionnaire we can see that very few respondents voted according to the campaign seen and more than half of the youth chose not on the awareness that parents generally did not influence their children in voting and more than half of the youth (respondents) felt a period of collapse towards the legislative elections in 2019 in pidie district.

The role of youth is very strategic in social and state life, both in terms of social, economic, cultural, and political. Today's politics are very high, this can be seen from the seriousness of youth in good and right politics. The quality of youth is for change to be confused in the future. Youth concern about politics, seems increasingly fade. This can be seen from the declining perception of youth in politics and in fact most of the youth are very likely to feel apathetic.

Youth understanding about elections must be improved, especially regarding voters who are still in the first stage, it is very important in holding elections giving their voting rights, the election of budding voters should know the vision, mission and programs and even the biographies of the legislative candidates to be elected. Thus, novice voters will have adequate consideration before deciding where to vote.

Every election 40 percent of the total voters belong to youth but there are 37 percent of youth classified as not voicing their choices due to work or no concern for politics. The level 
of youth awareness is indeed very low where the data obtained by the authors from the questionnaire distribution of some young men who came to be young were the majority who had received gifts from prospective candidates and the success team so they participated in the election.

Why do young people not play an active role in politics because of the noise that arises in the political world that is often preached so that the thinking of young people regard politics is always colored with disrespect and disharmony, and there is always a problem with the behavior of actors on the political stage who often do not agree with their promises to during the campaign. When analyzed further, most young people answered that there were many conflicts and problems caused by politics and promises that were not kept, so they felt that politics should be better left aside if there was nothing to take. For this reason, they chose not to be involved in politics, and were more concerned with what was more important in their opinion.

From the results of the study found $63 \%$ of youth use their voting rights and $37 \%$ do not use their voting rights. This is the benchmark for young people who are so apathetic towards the politics that are running in this country.

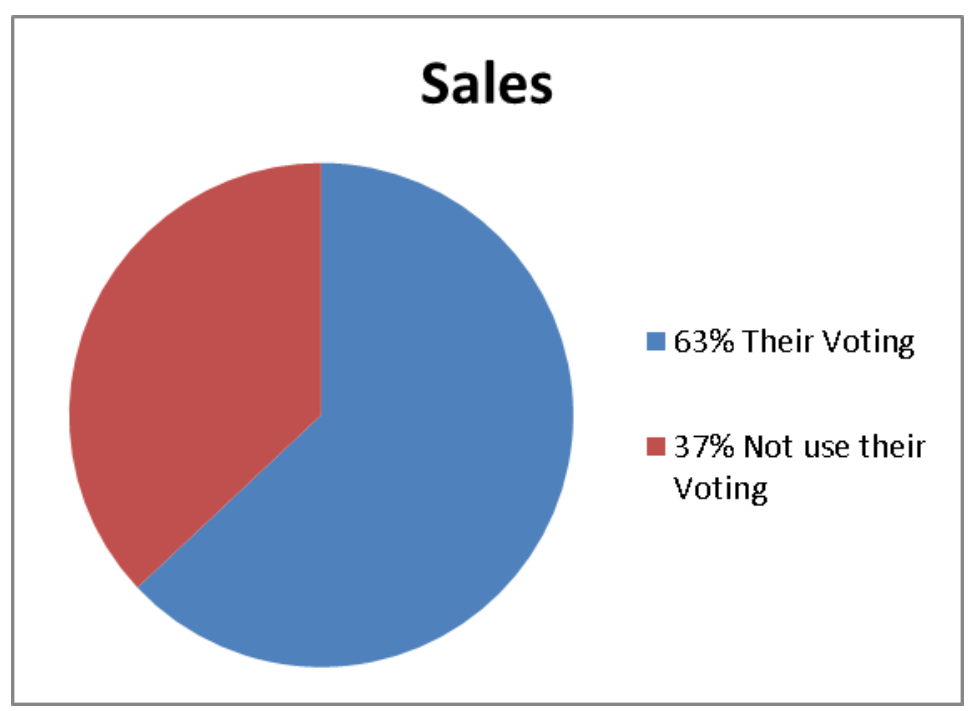

From the results of the above study, it can be concluded that young people who are included in the voting group almost half of them choose because of the financial factors and encouragement of others and very few choose according to conscience, although most of them often see and hear the campaigns of various candidates for the legislative interests. when youth in making their choices is very minimal and even most of them do not know the ability of the candidates that are carried, from the above explanation we can see that the perception of youth is classified as very low due to the many conflicts and problems caused by politics and promises that are not kept, so they feel this politics should be better put aside if there is nothing to take. For this reason, they chose not to be involved in legislative elections this year, and to take care of more important matters according to them. 


\section{Conclusion}

From the results of research that has been done, it can be concluded that

1) Lack of awareness of youth towards legislative elections.

2) More than half of young people choose not based on conscience and not based on the ability of legislative candidates

3) There is still money politics that is played by legislative canlon members

\section{References}

Arikunto, Suharsimi. (2010). Prosedur Penelitian Suatu Pendekatan Praktik. Rineka Cipta Yogyakarta.

Arikunto, S. (2013).Prosedur Penelitian: Suatu Pendekatan Praktik. Jakarta: Rineka Cipta. Asrori, Mohammad. (2009). Psikologi Pembelajaran. Bandung: CV Wacana Prima Bimo, Walgito. (2010). Pengantar PsikologUmum. Yogyakarta: C.V Andi Offset. Bungin, M. Burhan. (2008). Penelitian Kualitatif. Jakarta: Kencana Prenada Media Group Bungin, Burhan. (2011). Penelitian Kualitatif. Jakarta: Kencana Predana Media Group Matsumoto, David. (2008). Pengantar Psikologi Lintas Budaya. Pustaka Pelajar Yogyakarta. Prasetyo, G. (2019). Modern Paradigm: Democratic Skills in a Higher Order Thinking Skills Frame, Budapest International Research and Critics Institute-Journal (BIRCI-Journal). p. $150-159$.

Sumadiria, Haris. (2006). Jurnalistik Indonesia Menulis Berita dan Feature. Bandung: Simbiosa Rekatama Media.

Tricahyo, Ibnu. (2009).Reformasi Pemilu Menuju Pemisahan Pemilu Nasional dan Lokal, Malang : In-Trans Publishing, 